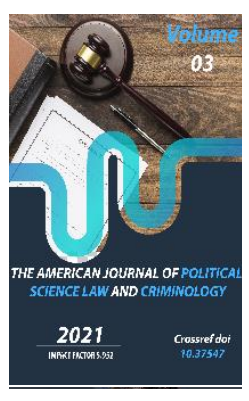

\title{
Judicial Tenure And Its Role In Securing Judicial Independence: Practices From Uzbekistan And The United States
}

\section{Botirjon Kosimov}

Senior Lecturer And Independent Researcher At Tashkent State University Of Law, Uzbekistan

Journal Website: http://usajournalshub.c om/index,php/tajpslc

Copyright: Original content from this work may be used under the terms of the creative commons attributes 4.0 licence.

\section{ABSTRACT}

This article analyzes judicial tenure and its impact on judicial independence in jurisdiction of Uzbekistan and the United States. The author gains critical insight into judicial tenure in both countries and offers a proposal to reconsider judicial tenure in Uzbekistan based on his empirical research.

\section{KEYWORDS}

Judiciary, judges, courts, judicial tenure, lifetime tenure, limited tenure.

\section{INTRODUCTION}

Due to the serious attention paid by the international community to the independence of the judiciary, over the past 25 years, the rules aimed at insulating the judiciary from external influences have increased in the drafting of constitutions around the world. Today, $77 \%$ of the world constitutions have declarative rules that the judiciary is an independent branch of government [1]. 
In general, constitutional rules [2] concerning the independence of the judiciary are provided in a form of declarative rules and explicit measures, such as judicial tenure and judicial salary, limiting the participation of the executive in the selection and dismissal of judges [3].

J. Melton and T. Ginsberg assert that declarative rules on the independence of the judiciary cannot fully guarantee the independence of the judiciary. The reason is that if judges make decisions which are unfavorable to other authorities, declarative rules cannot prevent their desire to act deliberately against judges. In addition, declarative rules make the independence of the judiciary into an abstract concept. Therefore, the constitution should include institutional protections to ensure judicial independence [4]. According to the Basic Principles on the Independence of the Judiciary, the independence of the judiciary must be enshrined in the constitution or law by the state [5].

I agree with the above-mentioned scholars, as the Constitution is an important political and legal document that must meet the urgent need for national regulation in the country and society [6].

The Constitution of the Republic of Uzbekistan reflects a tenure of the Oliy Majlis, the President, khakims and prosecutors. However, it does not provide rules clearly establishing judicial tenure. Reflection of judicial tenure in the constitution is of great importance in ensuring the independence of judges.

Judicial tenure is governed by the Constitutional Law "On the Constitutional Court of the Republic of Uzbekistan" and the
Law "On Courts". According to the Law "On Courts", a judge is appointed or elected for a term of 5 years for the first time, 10 years and for an indefinite term of office for the next time [7].

According to the law, the maximum age for judges of the Supreme Court of the Republic of Uzbekistan is 70 years, for judges of other courts -65 years, this age can be extended to 5 years and retains the right to retire when judges reach retirement age [8]. This means that judges in Uzbekistan are not elected or appointed for life.

However, the term of office of the Constitutional Court Justices is 5 years. In addition, the same person may not be elected a judge of the Constitutional Court more than twice [9]. The parliament has passed a the Law "On the Constitutional Court of the Republic of Uzbekistan" which is expected to be signed by the President, according to which Constitutional Court Justice are elected for a term of 5 years for the first time, 10 years for the next time. However, they are not secured an indefinite term of office.

In fact, it is debatable what the term of office of judges should be in order for the judiciary to be truly independent. U.Mingbaev emphasizes that it is expedient to appoint district judges for 5 years, regional judges for 10 years, judges of the Supreme Court for 15 years and, finally, judges of the Supreme Court who have demonstrated their potential for life [10]. A. Egamberdiev, G. Abdumajidov argue that the appointment or election of judges for life contributes to ensuring real judicial independence [11].

According to $M$. Redish, the authors of the United States Constitution sought to 
consciously protect judges from political pressure by creating constitutional rules related to the term of judicial office and the protection of judicial salaries [12].The Unites States Constitution reflects the legacy of judicial independence and this is regarded a constitutional value in American society [13].

Article III of the Constitution of the United States of America specifies that "The judges, both of the supreme and inferior courts, shall hold their offices during good behaviour..." [14]. This means that federal judges are guaranteed a lifetime term of office.

"During good behaviour" means that judges remain in office until they have committed an act prohibited by the United States Constitution. Therefore, in the Constitution, the wordings "during good behaviour" are used instead of the word "lifelong". The concept of "good behavior" was first provided in the Act of Settlement, enacted in England in 1701. Prior to this Act, the monarch would independently fix a term of office for each judge in individual letters patent [15].

Lifelong judgeship is regarded a guarantee for the independence of the judiciary, "Thus, once appointed they don't have to please their constituents to try to gain reelection, and can simply do their job... The lifetime term provides job security, and allows appointed judges to do what is right under the law, because they don't have to fear that they will be fired if they make an unpopular decision." [16] An unpopular decision is defined as any decision, which most people do not like. They can be such decisions related to gender equality [17], political rights [18], public affairs [19], labor migration [20], public health [21], civil society [22] and so on.
Since it is not possible to fully enumerate the acts of good behavior in the Constitution, the acts that are contrary to good behavior are mentioned. Article II, Section 4 of the United States Constitution provides "The President, Vice President and all civil Officers of the United States, shall be removed from Office on Impeachment for, and Conviction of, Treason, Bribery, or other high Crimes and Misdemeanors." This includes federal judges through the concept of "civil Officers" [23].

However, according to 28 U.S. Code § 371 judges may retire if they have reached a certain age. In this case, a retired judge is secured annual pension equal to annual income of the last year of the judicial office for the rest of his or her life. A judge who has reached the age of 65 may retire if he or she has served as a judge for 15 years and a judge who has reached the age of 70 for 10 years. Judges between the ages of 65 and 70 must have between 15 and 10 years of judicial experience, respectively in order to retire [24].

In addition, according to the Law "Judicial Conduct and Disability Act", adopted in 1980, any person alleging that a judge is unable to discharge all the duties of office by reason of mental or physical disability may file a written complaint [25]. In this case, a judge has the right to retire.

If a judge does not retire, the President appoints an additional judge with the advice and consent of the Senate. This means that no one can remove a judge from office by any means other than impeachment [26].

Along with scholars who support judicial life tenure, there are also critics of it. In particular, according to S. Prakash, it is a constitutional mistake that has been going on for centuries, 
when the lifelong term of judicial office should be abandoned [27]. This view is also supported by G. Calabresi and J. Lindren, who propose the establishment of a fixed and non-renewable 18year term of office instead of a lifetime term of office [28].

From among American states, judicial lifetime appointment has only been introduced in Rhode Island [29]. In Massachusetts and New Hampshire, judges are appointed for life, but until the age of 70 [30]. In the state of New Jersey, judges are appointed for 7 years and then until 70 years as the next term [31]. In some states, judges are appointed on a longterm basis. In Delaware, for example, judges are appointed for 12 years [32].

As the average life expectancy of Americans increases, so will the length of service of judges in the judiciary in the future. The first five judges of the U.S. Supreme Court have served for about nine years, but that number has now tripled [33].

Aged judges cause ineffectiveness in the administration of justice and in writing and declaring court decisions. Further, due to lifetime appointment of judges, the Supreme Court of the United States has been politicized and therefore, according to Ward, "scholarly consensus suggests an alternative of staggered, 18-year terms, allowing each president to nominate two justices every four years. Under this plan, each president would have the opportunity to leave his or her mark on the court, promoting democracy." [34]

D. Garrow [35] and L. Epstein, J. Knight, O. Shvetsova [36] assert that the only purpose of setting an age limit for judges is to prevent people with mental disorders from working as judges in the judiciary. Therefore, in many countries where lifelong judicial tenure has not been introduced, judges must retire at the age of 65 .

As a result of the recent judicial reforms [37], Uzbekistan has introduced a system of appointing or electing judges for the first time for five years, then for ten years and for an indefinite term of office [38]. However, a survey conducted among 75 judges demonstrates that there is a possible need for reconsideration of the current judicial terms. The judges was asked a question "How would your hearing a case, regardless of any influences, affect your chances of being elected or appointed to the next term?" 45.3\% of respondents answered "If I work on such a principle, it is highly unlikely for me to get to the next term of office", $14.7 \%$ provided the answer "I cannot say anything".

Judicial tenure has a great role in securing judicial independence. However, based on the survey results, we can conclude that in Uzbekistan from a de facto perspective, a judge elected for five years for an initial judicial term is not guaranteed reelection or reappointment for the next terms even if he or she decides a case lawfully in spite of any influence. This reflects a paradox between the purpose for reformed judicial tenure and the survey results.

Another survey question "Election and appointment of judges for life would secure their independence. Do you agree? " resulted that $77.3 \%$ of judges provided answered "Yes, I agree" while $22.7 \%$ - "No, I do not agree". Taking this survey result into account and the above mentioned negative aspects of the appointment of judges for life, I propose to elect and to appoint all judges in Uzbekistan for a limited tenure - until 65 in the future. 
This is important especially for the Justices of the Constitutional Court of the Republic of Uzbekistan as they make decisions that affect the life of the whole society. The ability of the Constitutional court to make decision independently of political pressure depends on the term of office of its justices [36]. Therefore, it is essential to elect Constitutional Court Justices for the same term as judges of general jurisdiction courts I proposed. This would ensure the same level judicial independence for the Constitutional Court Justices.

\section{REFERENCES}

1. Melton, J. and Ginsburg, T., 2014. Does de jure judicial independence really matter? A reevaluation of explanations for judicial independence. Journal of Law and Courts, 2(2), pp.187-217.

2. Б.Қосимов. Ўзбекистонда суд хокимияти мустақиллигининг конституциявий кафолатлари. Ўзбекистон қрнунчилиги тахлили, 2019/12. № 3, pp. 22-25.

3. Melton, J. and Ginsburg, T., 2014. Does de jure judicial independence really matter? A reevaluation of explanations for judicial independence. Journal of Law and Courts, 2(2), pp.187-217.

4. The Basic Principles on the Independence of the Judiciary. Adopted by the Seventh United Nations Congress on Crime Prevention and the Treatment of Offenders in Milan from 26 August to 6 September 1985 and approved by UN General Assembly Resolution 40/32 of 29 November 1985.

5. https://www.ohchr.org/en/professionalint erest/pages/independencejudiciary.aspx
6. Donald A. Ritchie. Our Constitution. Oxford University Press. 2006. p. 5.

7. Article 631 of the Law of the Republic of Uzbekistan "On Courts". Bulletin of the Oliy Majlis of the Republic of Uzbekistan, 2001, No. 1-2, Article 10. https://lex.uz/docs/68532

8. Article 661 of the Law of the Republic of Uzbekistan "On Courts". Bulletin of the Oliy Majlis of the Republic of Uzbekistan, 2001, No. 1-2, Article 10. https://lex.uz/docs/68532

9. The Constitutional Law "On the Constitutional Court of the Republic of Uzbekistan". Collection of laws of the Republic of Uzbekistan. National database of laws. https://lex.uz/docs/3221763

10. U.Mingboev. To have an independent judiciary. Democratization and human rights. 1/2013. p.19.

11. A.Egamberdiev. Constitutional guarantees of judicial independence. Law and Duty. № 11, 2010 й. pp. 54-55.

12. Redish, M.H., 1995. Federal Judicial Independence: Constitutional and Political Perspectives. Mercer Law Review, 46(2), p.6.

13. Kosimov, B., 2020. Threats to judicial independence: reflections on the US experience. TSUL Legal Report International electronic scientific journal, 1(1).

14. US Constitution. Article III. https://www.law.cornell.edu/constitution/ articleiii\#section1

15. Walter F. Pratt. Judicial Disability and the Good Behavior Clause, 85 Yale. L.J. 707 (1975-1976). p. 708.

16. http://judiciallearningcenter.org/judicialindependence/

17. Alieva, K., 2021. Trends In Ensuring Gender Equality: The Practice And Legal Reforms Of Advanced Foreign Countries. The 
American Journal of Political Science Law and Criminology, 3(03), pp.11-20.

18. Беков, И., $2020 . \quad$ ВОПРОСЫ КОНСТИТУЦИОННО-ПРАВОВОГО РЕГУЛИРОВАНИЯ ПРАВОВОГО СТАТУСА ПОЛИТИЧЕСКИХ ПАРТИЙ. Review of law sciences, 5(Спецвыпуск).

19. Юлдошев, А.Э., 2018. Онлайнперспективы общественных обсуждений законодательных предложений в Республике Узбекистан. In Информационные технологии и право: Правовая информатизация-2018 (рр. 349353).

20. Bekzod, M., 2020. PROBLEMS OCCURRING IN ORGANIZATION OF PRIVATE EMPLOYMENT AGENCIES'ACTIVITIES IN ENSURING EMPLOYMENT OF THE POPULATION AND THEIR SOLUTIONS. «Хуқуқий тадқиқотлар» электрон журнали, 4(5).

21. Сафарова, Х., 2020. СОВЕРШЕНСТВОВАНИЕ КОНСТИТУЦИОННО-ПРАВОВЫХ ГАРАНТИЙ ОБЕСПЕЧЕНИЯ ПРАВА ГРАЖДАН НА КВАЛИФИЦИРОВАННОЕ МЕДИЦИНСКОЕ ОБСЛУЖИВАНИЕ В УЗБЕКИСТАНЕ. Review of law sciences, 5(Спецвыпуск).

22. НАРИМАНОВ, Б., 2020. ЎЗБЕКИСТОНДА НОДАВЛАТ НОТИЖОРАТ ТАШКИЛОТЛАР ТАРИХИ ВА РИВОЖЛАНИШИНИНГ АСОСИЙ ТЕНДЕНЦИЯЛАРИ. ЮРИСТ АХБОРОТНОМАСИ, 1(3), pp.18-29.

23. https://constitution.congress.gov/constitu tion/

24. 28 U.S. Code $\S 371$ - Retirement on salary; retirement in senior status. https://www.law.cornell.edu/uscode/text/ $28 / 371$
25. 28 U.S. Code $\S 351$ - Complaints; judge defined.

https://www.law.cornell.edu/uscode/text/ $28 / 351$

26. 28 U.S. Code $\S 354$ - Action by judicial council.

https://www.law.cornell.edu/uscode/text/ $28 / 354$

27. Saikrishna B. Prakash. America's Aristocracy. 109 YALE L.J. 1999. p. 581.

28. Calabresi, S.G. and Lindgren, J., 2005. Term limits for the Supreme Court: Life tenure reconsidered. Harv. JL \& Pub. Pol'y, 29, p.769.

29. Rhode Island Constitution. Article $X$. http://www.rilin.state.ri.us/riconstitution/P ages/C10.aspx

30. Massachusetts Constitution. Article XCVIII. https://malegislature.gov/laws/constitutio n\#chapterlIIArticlel

31. New Hampshire State Constitution. Article 73. https://www.nh.gov/glance/judicial.htm

32. New Jersey State Constitution. Article VI Section VI. https://www.njleg.state.nj.us/lawsconstitu tion/constitution.asp

33. Delaware Constitution. Article IV, § 3 . http://delcode.delaware.gov/constitution/ constitution-05.html

34. http://www.supremecourt.gov/about/biog raphyScalia.aspx

35. http://qz.com/624925/the-supreme-courtslifetime-appointments-are-ineffective-andborderline-autocratic/

36. Garrow, D.J., 2000. Mental decrepitude on the US Supreme Court: The historical case for a 28th amendment. U. Chi. L. Rev., 67, p.995. 
Doi: https://doi.org/10.37547/tajpslc/Volume03Issue04-19

37. Epstein, L., Knight, J. and Shvetsova, O., 2001. Comparing judicial selection systems. Wm. \& Mary Bill Rts. J., 10, p.7.

38. Косимов, Б., 2020. ТЕНДЕНЦИИ ОБЕСПЕЧЕНИЯ НЕЗАВИСИМОСТИ СУДЕБНОЙ ВЛАСТИ В УЗБЕКИСТАНЕ И СОЕДИНЕННЫХ ШТАТАХ АМЕРИКИ: СРАВНИТЕЛЬНЫЙ АНАЛИЗ. Review of law sciences, 1 (Спецвыпуск).

39. Article 631 of the Law of the Republic of Uzbekistan "On Courts". Bulletin of the Oliy Majlis of the Republic of Uzbekistan, 2001, No. 1-2, Article 10. https://lex.uz/docs/68532 $\mathrm{F}$ 